\title{
French deep-sea hinterlands: Some empirical evidence of the spatial impact of containerization
}

\author{
David Guerrero, Ifsttar, SPLOTT
}

\begin{abstract}
Two distinct types of ports handle the French deep-sea cargo. Global ports of Northern Range and Marseilles act as the source for a number of overseas regions (forelands) and secondary ports mainly serve niche markets. In this paper we demonstrate that global ports serve also larger hinterlands, but their prominence over secondary ports depends on the types of cargo handled. The results of our spatial interaction model demonstrate that most of types of cargo flows are strongly constrained by distance. This indicates that, despite a deep transformation on forelands, the secondary ports subsist because they partly depend on niche markets and largely on local economies generating substantial amounts of non-containerized cargo flows. Some implications of this finding are explained.
\end{abstract}

Key Words: Hinterland, Foreland, Containerisation, France, Spatial Interaction Model

\section{Introduction: the concept of hinterland is it still relevant?}

An attempt has been made to elucidate the spatial structure of French hinterlands after four decades of containerization in this study. The detailed hinterland analysis developed by Charlier $(1981,1991)$ is updated by extending it to the period $1995^{-} 2005$ and to 95 inland regions.

We first define 'hinterland_ as it is central to this paper. The concept of hinterland and its overseas equivalent term foreland_were mainly explained before containerization in the middle of $20^{\text {th }}$ century (Sargent, 1938, Amphoux, 1950). Both refer to the inland areas served by ports (Weigend, 1956). As seen in Figure 1, the hinterland of the port [|a] is an inland area [A] that delimits the points of origin and destination of maritime shipments handled by the port [a] Conversely, the foreland of the same port [a] is the set of inland areas served by the port [a] by means of maritime transportation $[\mathrm{B}, \mathrm{C}]$. By this definition, a single area $[\mathrm{A}]$ acts as the hinterland of one port [a] and also forms part of the forelands of other ports [b and c]. In this schematic context, the hinterland is a spatially continuous area and the foreland is a discontinuous set of land areas interconnected by maritime links. This scheme also postulates exclusive hinterlands that are spatially concentrated around ports. However, this is not always the reality. As early as 1918, Demangeon observed substantial overlap between the hinterlands of the ports of Antwerp, Amsterdam, and Rotterdam (Demangeon, 1918).

Containerization has challenged the hypothesis of captive hinterlands that are spatially concentrated around ports. Between 1960s and 2000s, container has brought important changes in liner shipping. In containers, many kinds of cargo can be transported on the same ship, and each container can be easily transferred from one means of transport to another without unpacking. Containerization leads to significant economies in handling and maritime 
transport (De Neufville and Tsunokawa, 1981). However, the high capital cost of container ships and handling tools necessitate a push for its maximum utilization. This push predisposes spatial concentration of freight flows at one or two big ports by region, marginalizing all other ports, as demonstrated by Mayer (1978). He observed that the combined effect of development of container shipping and the completion of interstate highway network increases the competitive advantages of main ports, also called `load centers_. These ports are usually located close to large markets and/or to main maritime routes. The spatial impact of containerization has been an ongoing area of study for transportation geographers. Hayuth (1981) was the first to formalize the load center concept by developing a spatial model inspired by Taaffe et al. (1963) and Rimmer (1967). The concept explains how the development of a hub-and-spokes network leads to concentration of cargo flows in a few ports, inland centres, and transport routes. The further evolution of the port system might lead to deconcentration, when cargo shifts from large ports to smaller or new ports (Hayuth, 1981, Notteboom, 2005, Frémont and Soppé, 2007).

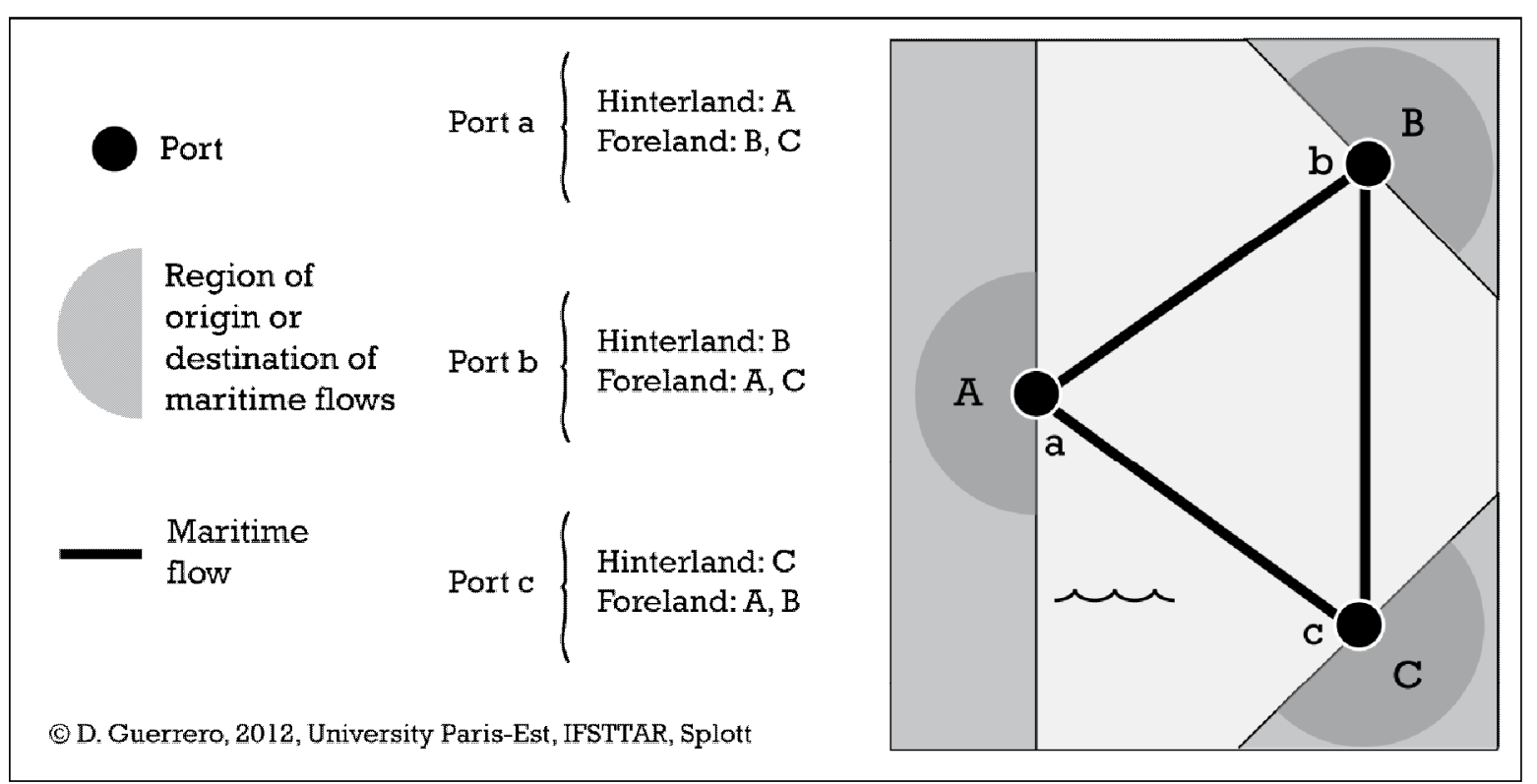

Figure 1. Schematic representation of hinterlands and forelands

Several regional studies provided empirical evidence for the consequences of containerization on hinterlands and forelands. Hoare (1986) found a large overlapping of hinterlands of British ports. He argued that containerization results in shippers preferring to concentrate trade and services to particular overseas destinations at particular ports. Similarly, Slack (1990) found, in a continental context of the United States, that the development of rail services across the country contributed to the concentration of an increasing share of Far Eastern Trade on the ports of the West Coast to the detriment of those of the East Coast. In both the cases, shippers attempted to minimize the maritime segment of their exports, even if it implied longer inland haulages. They reasoned that the increase of inland haulage can be compensated by overall cost saving achieved by speed of flow and through inland handling costs (Hoare, 1986). The geographic configuration of mainland Europe is different, and the distance between ports and markets is generally short, even if it were be increased by the development railway corridors to the hinterland (Van Klink \& Van den Berg, 1998).

The developments discussed above clearly demonstrate that the development of containerization has transformed port hinterlands. Some scholars even go so far as to say that hinterlands 'no longer matter[s]_. (Hoare, 1986). Although the increase in inter-port 
competition as a result of containerization has been largely proved (Veldman and Buckmann, $2003, \mathrm{Ng}, 2006$ ), empirical investigation on the changes of hinterlands due to containerization remains scarce, largely because of lack of data. Therefore, the purpose of this paper is to study the containerization impact on port hinterlands by providing empirical evidence.

The rest of this article is structured as follows. Our hypotheses are explained in Section 2 and an overview of the data and methods used are provided. Section 3 examines how French hinterlands are shared between global and secondary ports. Section 4 introduces a spatial interaction model to measure the differences between hinterlands for different types of cargo. Section 5 explores the link between hinterland and foreland for the two main French container ports, Le Havre and Marseilles, for trade with United States and East Asia. Section 6 presents the conclusions and some implications for policymakers.

\section{Analyzing French hinterlands: Data and methods}

When studying maritime flows at a national level, delineating hinterlands proves to be difficult. Even only if the ports located inside France are taken into account, some big ports such as Le Havre and Marseilles obviously serve wider territories. In addition, other ports located outside France (like Antwerp and Rotterdam) also handle French cargo flows.

Unfortunately, in Western Europe a large-scale geographic database of freight flows is not available as in the United States (PIERS). Empirical evidence on freight flows can be gathered only from enquiries (shippers survey), which are not comprehensive on a E.U.-wide basis. For these reasons, we decided to make use of national data, although we know it is an imperfect proxy of a much wider phenomenon.

Information about freight flows is available from databases generated by French Foreign Trade Statistics Bureau (2005), providing disaggregated and exhaustive data of the value and weight of trade (in euros and tonnes). We collected data of Foreign Trade Flows for 1995, 1999, 2003, and 2005. The advent of an internal European Union market on the January 1, 1993 that led to removal of customs formalities (the traditional source of statistical data on international trade) between Member States enforced the adoption of a new data collection system, Intrastat, as the basis for statistics on intra-EU trade. The introduction of Intrastat involved a methodological break with the past and reduced the quality of statistics. But these changes have not affected much of the customs formalities for EU trade outside EU (imports and exports). For these reasons, we made use of data available for French maritime trade outside EU. This narrows the focus of this paper to deep-sea freight flows.

The year 2005 was chosen for this study. Since 2007, with new simplifications of Customs declarations, trade data in tonnes is no more available. This development implied a lowering of data quality after 2007, since goods having the same value can have very different weights, and then be carried in a very different manner. The authors are aware that change happens in hinterlands rather slowly and therefore have decided to adopt 2005 data in euros and tonnes instead of more recent data only in euros.

The spatial units used are the départements ${ }^{1}$, French equivalent of Chinese 'xiàn,_. U.S. counties, Japanese `ken,_ or European NUTS-3. We selected 94 mainland départements, excluding those of Corsica and Overseas French Territories.

\footnotetext{
${ }^{1}$ Appendix 2 presents the spatial distribution of French maritime trade outside EU in the départements.
} 
Customs offices located in French ports were aggregated into ports (Figure 4). Information about ports of foreign countries that handle French foreign trade is only available at the country level. Then, we have divided the ports into two types of entities: (a) 16 individual ports located in France and (b) 5 foreign country port sets, which handle together $98 \%$ of the value and $97 \%$ of the tonnes of French foreign trade.

The truck time-distances between centroids of départements and ports used in the spatial interaction model have been extracted from ESPON inter-NUTS-3 distance database created by Spiekerman and Wegener in 2005.

The French Foreign Trade Statistics Bureau (2005) distinguishes between 10 different types of cargo. There is no specification between liner _ service, which operates on a fixed geographic itinerary and publicly advertised sailing schedule, and 'tramp _ service, which operates on an irregular or chartered schedule. In this paper, we consider that liner cargo mainly consists of manufactured goods, usually of high value, including machinery and vehicles. Containerized shipping is assumed to be a subcategory of liner service.

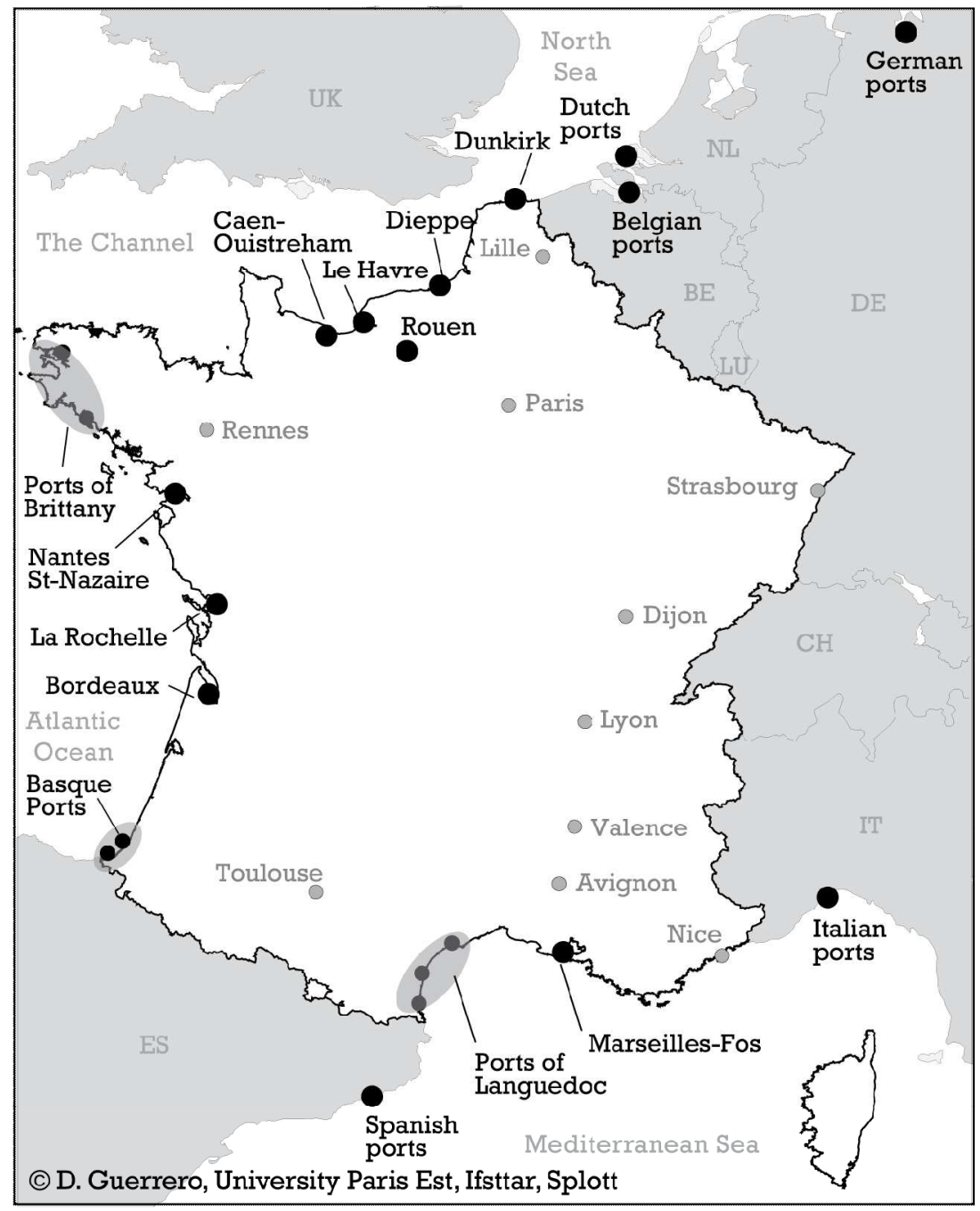

Figure 2. Ports (and sets of ports) handling French extra-EU Trade (2005)

A cluster analysis was done on French départements to map their main orientation to ports. The method employed is an ascendant hierarchical classification, obtained from a cross-table of ports and départements. The metric used is distance to chi square, in order to limit the mass 
effects linked to the largest ports. This method of classification allows characterizing of each département with respect to the average French profile, depending upon the ports or the sets of ports that handle its maritime cargo flows.

A spatial interaction model is employed to analyze the hinterlands for different types of cargo. It allows us to explain the spatial distribution of flows between the ports and the départements, in terms of volumes of trade (in tonnes) of départements and ports and the distance between both. The spatial interaction model used is formulated as follows:

$$
\frac{? \mathrm{i}(\mathrm{i} \cdot \mathrm{Bj}(\mathrm{j}}{\operatorname{dij}}
$$

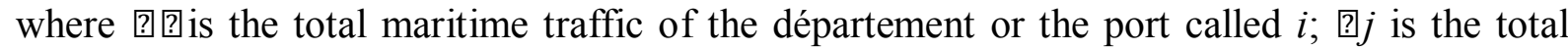
maritime traffic of the département or the port called $j$ (see table 1); 国阳 is the distance between $i$ and $j$; $a$ is the distance decay parameter; and ? $i$ and $\} j$ are the balancing factors ensuring that the origin $i$ and destination $j$ constraints are satisfied. When a département or a port sends freight traffic, it is referred to as $\dddot{i}_{-}$and when a département or a port receives this traffic, it is referred to as region $\dddot{j}$.

The choice of measure of distance influences the results of the spatial interaction model. The truck $\breve{s}$ time-distance has been selected because it seems to be more consistent in the context

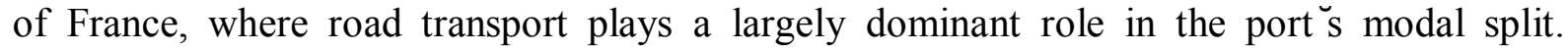
Moreover, the explanatory power of the model is slightly higher when the truck time-distance is used, as compared to the Euclidean distance.

The data finally used is a matrix of freight flows, usually measured in annual tonnes moved. The value of $]^{[0}$ is the part of the total variance explained by the model. It is a measure of the goodness of fit of the model to explain the spatial distribution of flows between the ports and the départements. An of $100 \%$ would indicate that the regression line perfectly fits the data. This means that the spatial distribution of flows between ports and départements can be perfectly predicted by the total traffic of each port, total traffic of each département, and the distance separating both. A second $]^{\text {[ }}$ is calculated as a measure of variance specifically explained by distance.

A Poisson regression has been used to fit the spatial doubly constrained model (Fotheringham and O Kelly, 1989, D Aubigny et al., 2000).

Table 1. The matrix of the origin ${ }^{-}$destination of flows between ports and départements

\begin{tabular}{|c|c|c|c|c|c|c|c|c|c|}
\hline From ${ }^{T o}$ & Port1 & Port2 & Port... & Portj & Dept1 & Dept 2 & Dept... & Deptj & Total \\
\hline Port1 & 0 & 0 & 0 & 0 & I11 & I12 & ǔ & $\mathrm{I} 1 \mathrm{j}$ & Tport1 \\
\hline Port2 & 0 & 0 & 0 & 0 & I 21 & I22 & ǔ & $\mathrm{I} 2 \mathrm{j}$ & Tport2 \\
\hline Port... & 0 & 0 & 0 & 0 & ǔ & ǔ & ǔ & ǔ & ǔ \\
\hline Porti & 0 & 0 & 0 & 0 & Ii 1 & Ii2 & $\check{u}$ & Iij & Tporti \\
\hline Dept1 & I11 & I12 & ǔ & $\mathrm{I} 1 \mathrm{j}$ & 0 & 0 & 0 & 0 & Tdept 1 \\
\hline Dept2 & I21 & I 22 & ǔ & $\mathrm{I} 2 \mathrm{j}$ & 0 & 0 & 0 & 0 & Tdept2 \\
\hline Dept... & ǔ & ǔ & ǔ & ǔ & 0 & 0 & 0 & 0 & ǔ \\
\hline Depti & Ii1 & Ii 2 & ǔ & Iij & 0 & 0 & 0 & 0 & Tdepti \\
\hline Total & Tport1 & Tport2 & $\check{u}$ & Tportj & Tdept 1 & Tdept 2 & ǔ & Tdeptj & $\mathrm{T}$ \\
\hline
\end{tabular}




\section{France: A shared territory between global and secondary ports}

In France, Le Havre and Marseilles are the main ports and have been pioneers in containerization (Guerrero and Rodrigue, 2014). As soon as 1950 researchers already found that these two ports served more overseas regions than the other ports (Amphoux, 1950, Vigarié, 1964). Later, in the late 1980s, Marcadon (1988) showed that most of small and middle-sized ports only acted as the node for one or two overseas regions at most, mainly niche markets linked to tramp or short sea shipping. The trade handled by small and middlesized was mainly oriented to the intra-European short sea shipping (United Kingdom, Scandinavian countries) and to the former French colonies in Africa. Between these two distinct packages of ports remained an intermediary category of middle-sized ports of Dunkirk, Bordeaux, Nantes and Sète that serve less overseas regions than the main ports, but much more than the other ports. The resistance to this categorization of intermediary ports could be partly explained by inequalities in containerization rates between various regions of the world in the early 1980s. Marcadon evokes the example of the ports of Sudeste (Brazil), where containerization was less developed. The French shipping company CGM offered adapted services to the handling capacities of South American ports where containerized lines served the East Coast and mixed ships served the West Coast.

In the 2000s, containerization in France proceeded to expand well beyond the level reached in the early 1980s. Most of French deep sea flows of manufactured goods are now transported by the container. In $2012^{2}$, the main container ports serving France were Le Havre $(2.3 \mathrm{M}$ TEUs) on the Northern Range, Marseilles (1 M TEUs) on the Mediterranean, and the foreign Northern Range ports of Antwerp (8.6 M TEUs) and Rotterdam (11.9 M TEUs), which handle a part of French container flows. Other much smaller container ports are Dunkirk and Rouen (0.2 M TEUS each) in the Northern Range, and Nantes-Saint-Nazaire (0.2 M TEUs) and Bordeaux (0.1 M TEUs) in the Atlantic.

In a work on port specialization in terms of French foreign trade, Le Havre and the foreign ports of Northern Range (Antwerp, Rotterdam) have been ranked the closest to being regarded as truly global ports (Guerrero, 2010). Most of small and middle-sized ports are specialized in Europe and Africa forelands, both with regard to imports and exports. Marseilles and Dunkirk enjoy an intermediate position: they are rather close to the small and middle-sized ports for imports and could be termed nearer to global level for exports. In the case of manufactured goods, mostly containerized, Marseilles logically joins the group of global ports for both imports and exports as it handles significant amounts of cargo with main deep-sea markets of East Asia and North America. Finally, a clear hierarchy can be observed between global container ports and secondary ones. The latter are specialized in tramp or short sea shipping markets, mainly linked to Africa, Europe (non-EU countries), and the Middle East (Guerrero, 2010). These results are consistent with those of Gouvernal et al. (2010), confirming that the majority of deep-sea consignments pass through main container ports. A comparison of the forelands of 2005 with those of the early 1980 s indicate dramatic changes, essentially driven by containerization.

The first change is the widening of the gap between global and secondary ports. The structure of forelands follows a hierarchy closer to container shipping: the more diversified forelands are those of the main container ports (Northern Range ports and Marseilles). These ports are global in nature because they handle trade between France and most of the overseas regions.

\footnotetext{
${ }^{2}$ Source : CI Online.
} 
The intermediary category of middle-size ports no longer exist. The hub and spokes networks of container transportation tend to marginalize ports that are not close to the main routes or main hinterlands.

A second change is the decline in traffic for many overseas regions served by the port of Marseilles, especially for imports. Beyond labor factors (strikes) that are the explanation, there is a deeper reason linked with the geographical position of Marseilles in the main maritime routes of container shipping. The traffic of the port of Marseilles, located at the north of Mediterranean, is essentially generated by its hinterland. Since the development of container hubs in the south of the Mediterranean, shipping companies have started increasingly serving Marseilles by feeder (Notteboom, 1997, Gouvernal et al., 2005).

In 1980s, in the early stages of containerization, Charlier showed, in the French context, that global ports also had larger hinterlands (Charlier, 1981, 1991). He also pointed out that overlapping between distinct hinterlands only takes place at the margins, which he called ‘competition margins. _ This finding for France was slightly different from the `substantially overlapping _ hinterlands observed by Hoare for British ports during the same period.

The analysis of Charlier (1981) is updated after four decades of containerization in our study. In order to make our results suitable for an international audience, we have developed a simplified typology dividing hinterlands into four types, depending on the ports that handle their cargo (Figure 3): 


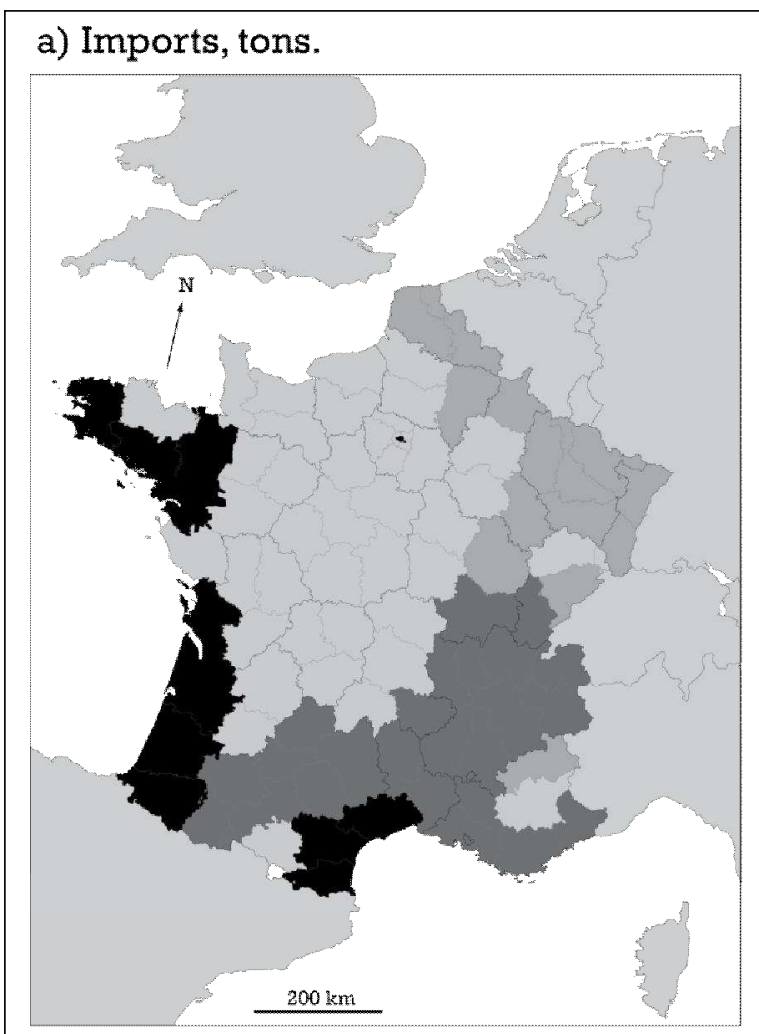

\section{b) Imports, euros.}

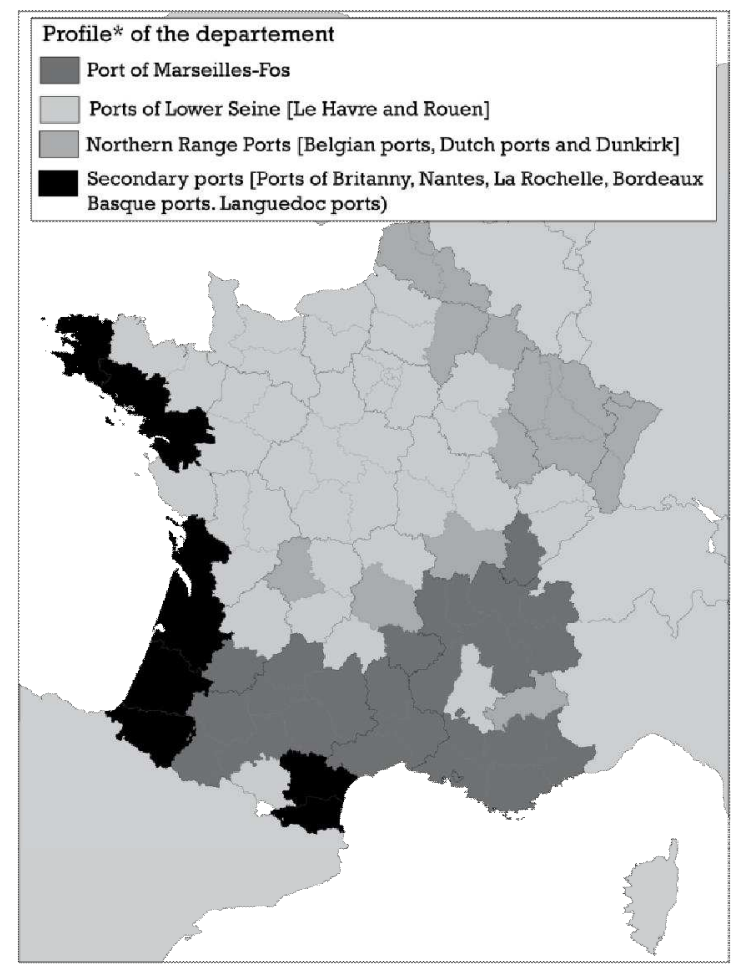

\section{c) Exports, tons.}

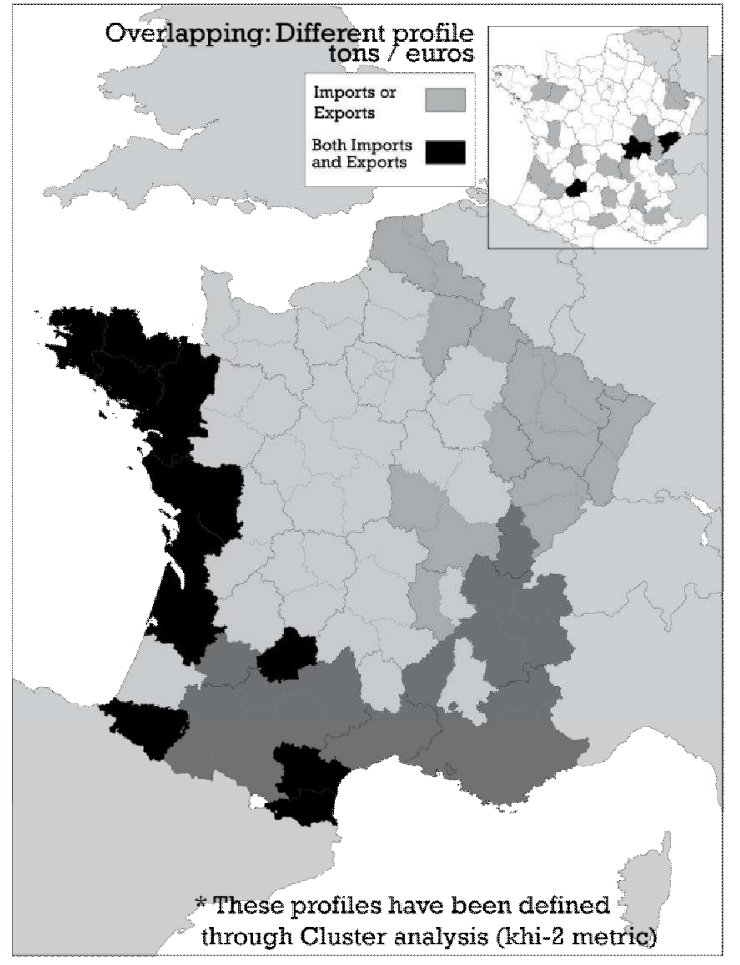

d) Exports, euros.

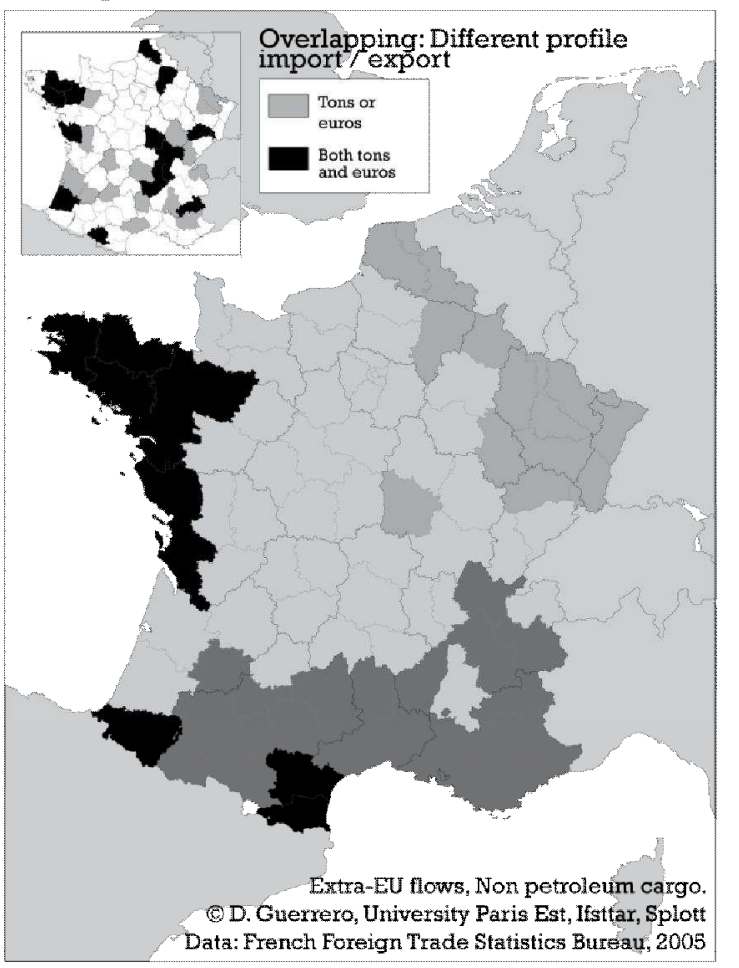

Figure 3. French hinterlands of global and secondary ports

The Lower Seine ports (Le Havre and Rouen) are analyzed together. These ports handle a large share of the cargo of the départements located in the north-west and the center of France. These two ports are largely complementary to each other, with Le Havre handling general cargo mostly in containers, whereas Rouen handles bulk cargo. Rouen is an urban 
upstream port that mainly handles bulk quantities. It is the main European port for exports of wheat produced in the French Northern Plains. Le Havre serves the industry in its vicinity (i.e. Renault) and also the region of Paris in which a very high share of French population and GDP is concentrated. Both ports handle substantial amounts of petroleum products, but petroleum traffic has been excluded from this analysis, because their enormous volume is too strong an influence on the result of the model compared to other types of cargo.

The hinterland of the port of Marseilles covers the départements located in southern France, almost up to Lyon in the East and Toulouse in the West, with both city regions generating substantial amounts of general cargo. Significant amount of bulk cargo is generated by the chemical industry, metallurgy, and agriculture. Marseille has good maritime connections with Northern Africa, East Asia (except Taiwan, with CKYH alliance ${ }^{3}$ ), former USSR countries, and the Middle East.

The foreign ports of the Northern Range and Dunkirk share common hinterlands in the north and east of France. They handle a high share of maritime cargo generated by the départements located on the northern and eastern boundaries of France and much larger areas around Strasbourg, Dijon, and in some cases up to Lyon.

The secondary ports essentially have local hinterlands, and sometimes even less. Some of these ports are located on the Atlantic coast and in the Mediterranean close to France $s$ boundary with Spain. The traffic they generate is a result of activities on a smaller scale such as in agriculture, animal farming, forestry products, chemical products, and building materials.

Globally, hinterlands show little variation on the basis of weight or value. More important variations can be found when imports and exports are compared. The core of the hinterlands of global ports remains rather unchanged; what really changes are the margins. Overlapping between the hinterlands of global and secondary ports is often the result of complementarity. While the global ports handle manufactured cargo flows, the smaller ports take care of bulk cargo, mainly related to agriculture and animal farming. Overlapping between the hinterlands of global ports is much likely due to real competition. This competition takes place essentially in eastern France and mainly concerns the areas of Dijon and Lyon. Secondly, the area around Lille and the regions close to France $\breve{s}$ border with Belgium are shared between Belgian ports and Dunkirk, and the Lower Seine ports, as outlined before by Charlier (1996, 2011). The influence of Dutch ports is much stronger on the region of Strasbourg, which is well connected to Rotterdam by the Rhine waterway. Most of time, hinterlands are spatially continuous, but some exceptions exist, mainly around Lyon, where rude competition exists between all the global ports.

\section{Inland distance matters but not in the same ways for all types of cargo}

All types of cargo flows are not equally constrained by distance. The doubly constrained spatial interaction model is used to measure these differences. The distance-decay parameter (国) can be interpreted as a measure of the decrease of flows between ports and départements with distance, other things being equal. A distance-decay parameter of 0 means that the inland

\footnotetext{
${ }^{3}$ Cosco/K Line/Yang Ming/ Hanjin
} 
location of a shipper has no influence on port choice. A distance-decay parameter of ${ }^{-} 5$ means that the nearest port is systematically selected. This "distance decay" or "friction of distance" effect varies depending on the type of flows being examined, for example, manufactured cargo as opposed to ores. 
Table 2. Results of the spatial interaction model

\begin{tabular}{|c|c|c|c|}
\hline \multirow[b]{2}{*}{ Type of cargo } & & $\begin{array}{c}\text { Explanatory power of } \\
\text { model (mass and distance) }\end{array}$ & \multirow{2}{*}{$\begin{array}{c}\text { Specific explanatory power } \\
\text { of distance }\end{array}$} \\
\hline & & $\mathrm{r}^{2}$ & \\
\hline Agricultural products & $-3,1$ & $92 \%$ & $78 \%$ \\
\hline Import & $-1,8$ & $71 \%$ & $42 \%$ \\
\hline Export & $-3,9$ & $97 \%$ & $90 \%$ \\
\hline Animal Food & $-2,2^{-}$ & $83 \%$ & $67 \%$ \\
\hline Import & $-2,1$ & $86 \%$ & $66 \%$ \\
\hline Export & $-2,4$ & $81 \%$ & $59 \%$ \\
\hline Fertilizers & $-3,8^{<}$ & $91 \%$ & $83 \%$ \\
\hline Import & $-4,0$ & $93 \%$ & $88 \%$ \\
\hline Export & $-3,8$ & $90 \%$ & $77 \%$ \\
\hline Solid Mineral Fuel & $-3,8^{-}$ & $82 \%$ & $50 \%$ \\
\hline Import & $-3,8^{-\cdots}$ & $79 \%$ & $50 \%$ \\
\hline Export & $-3,1$ & $61 \%$ & $36 \%$ \\
\hline Petroleum products & $-4,4^{<}$ & $97 \%$ & $92 \%$ \\
\hline Import & $-4,4$ & $97 \%$ & $91 \%$ \\
\hline Export & $-4,3$ & $99 \%$ & $98 \%$ \\
\hline Ores and waste materials of the metallurgical ind. & $-5,1{ }^{<}$ & $94 \%$ & $83 \%$ \\
\hline Import & $-5,6^{<}$ & $95 \%$ & $87 \%$ \\
\hline Export & $-3,8$ & $85 \%$ & $69 \%$ \\
\hline Metallurgical products & $-3,3$ & $89 \%$ & $72 \%$ \\
\hline Import & $-3,8$ & $84 \%$ & $57 \%$ \\
\hline Export & $-3,0$ & $92 \%$ & $75 \%$ \\
\hline Building Materials & $-2,6$ & $87 \%$ & $74 \%$ \\
\hline Import & $-2,9$ & $83 \%$ & $64 \%$ \\
\hline Export & $-2,4-$ & $91 \%$ & $77 \%$ \\
\hline Chemical products & $-2,1$ & $82 \%$ & $62 \%$ \\
\hline Import & $-3,3$ & $88 \%$ & $77 \%$ \\
\hline Export & $-1,3^{-}$ & $80 \%$ & $43 \%$ \\
\hline Manufactured goods & $-1,4$ & $69 \%$ & $38 \%$ \\
\hline Import & $-1,5$ & $76 \%$ & $44 \%$ \\
\hline Export & $-1,4$ & $65 \%$ & $30 \%$ \\
\hline Total cargo with petroleum products & $-3,0$ & $93 \%$ & $83 \%$ \\
\hline Import & $-3,3$ & $94 \%$ & $84 \%$ \\
\hline Export & $-2,7^{-}$ & $92 \%$ & $81 \%$ \\
\hline Total cargo & $-2,7^{-}$ & $86 \%$ & $75 \%$ \\
\hline Import & $-2,7$ & $83 \%$ & $72 \%$ \\
\hline Export & $-2,6$ & $88 \%$ & $75 \%$ \\
\hline \multicolumn{4}{|c|}{$\begin{array}{l}* * * \text { Very Significant } * * \text { Significant } \quad \prec \text { No significant } \\
* \text { Slightly Significant }\end{array}$} \\
\hline Extra-EU French $\mathrm{N}$ & ime Flo & etween départements and po & (2005) \\
\hline
\end{tabular}




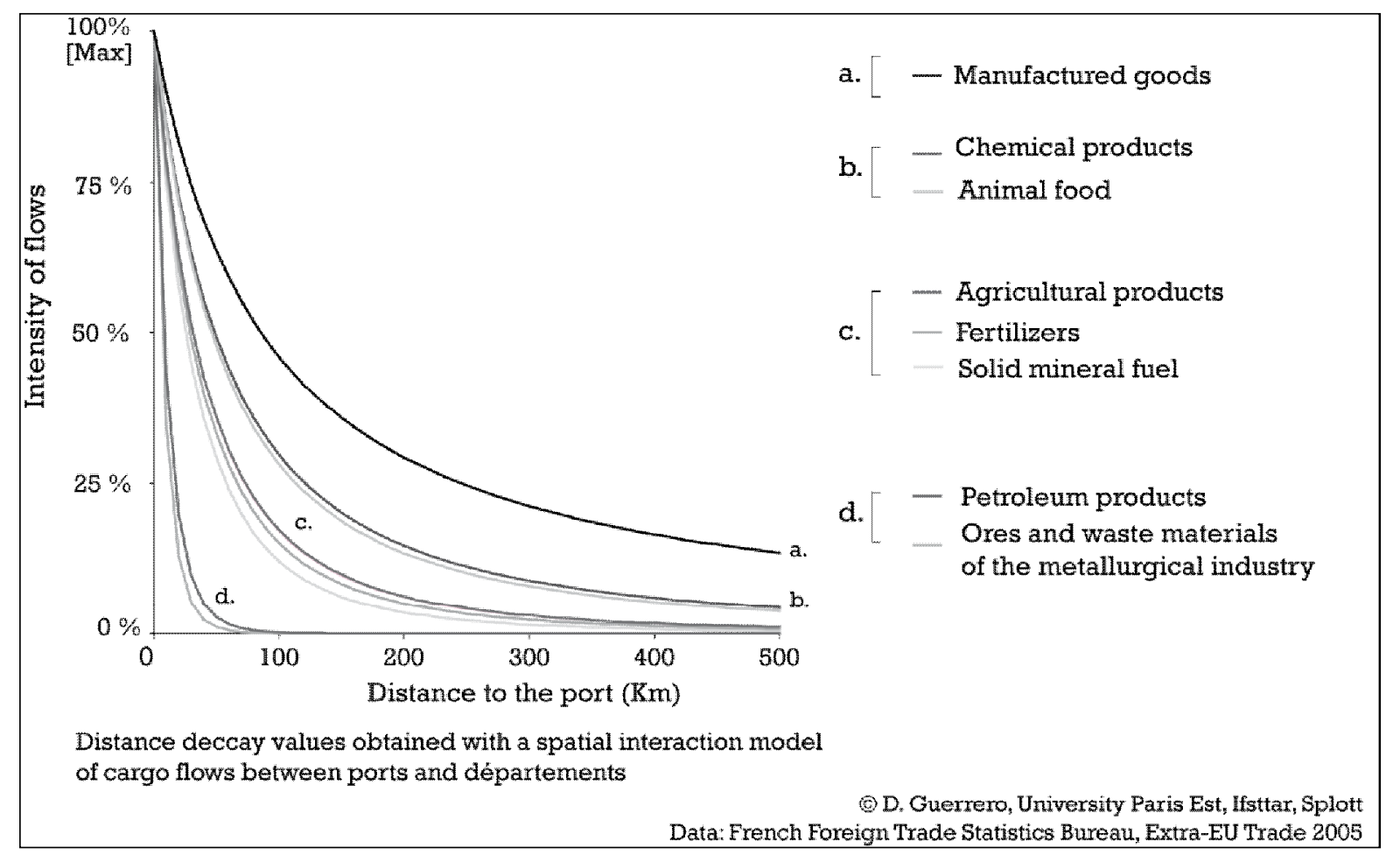

Figure 4. Relationship between the distance to the port and the intensity of cargo flows

Table 2 shows the results of the spatial interaction model. The average value of distancedecay parameter (? ? for all types is ${ }^{-} 2,7$ (flows in tonnes, without petroleum products), which means a rapid decrease of the intensity of inland flows with an increase in distance. The results for imports $(-2,7)$ and for exports $(-2,6)$ are more or less equal and can be compared with the spatial patterns observed in the maps analyzed above (Figure 3). The results of the spatial interaction model show that French hinterlands are strongly distance-constrained. The maritime flows of the départements are usually handled by the nearest ports. From the point of view of the ports, links with local areas tend to be more intense. This finding is consistent with the concept of primary hinterlands _ introduced by Morgan (1948), but in the case of French ports, local areas are not necessarily captive, as will be shown later in this paper.

The estimated distance-decay parameters vary significantly between types of cargo (see Figure 4). The highest (? ? values have been obtained for flows of ores and waste materials of metallurgy $\left({ }^{-} 5,1\right)$ and petroleum products $(-4,4)$. Other highly distance-constrained flows are those of solid mineral fuel $($ ? $=-3,8)$, fertilizers $($ ? $=-3,8)$, metallurgical products $($ 圆 $=-3,3)$, and agricultural products $($ ? $=-3,1)$. The (? ? values obtained for the other types of cargo are weaker than the average: building materials $($ ? $=-2,6)$, animal food $($ ? $=-2,2)$ and chemical products $($ ? $=-2,1)$. The inland flows of manufactured products ${ }^{4}$ are least constrained by distance $($ ? $=-1,4)$. The value of friction obtained on manufactured flows in France is found to be higher than those obtained in the models of Pitts (1994) and Levine et al. (2009) for U.S. container imports and exports.

\footnotetext{
4 The Appendix 3 presents French hinterlands of manufactured cargo, using the same method of the figure 5.
} 
For all types of cargo, the explanatory power ([?] $\left.{ }^{[]}\right)$of the combined effect of mass (tonnes generated by ports and départements) and distance is high (between $69 \%$ for manufactured goods and $94 \%$ for ores and waste materials of the metallurgical industry). Moreover, the variance specifically explained by distance $\left(\mathrm{r}^{\text {Q }}\right.$ ) provide interesting information on the degree of overlap between hinterlands of ports, without considering the mechanical effect of mass.

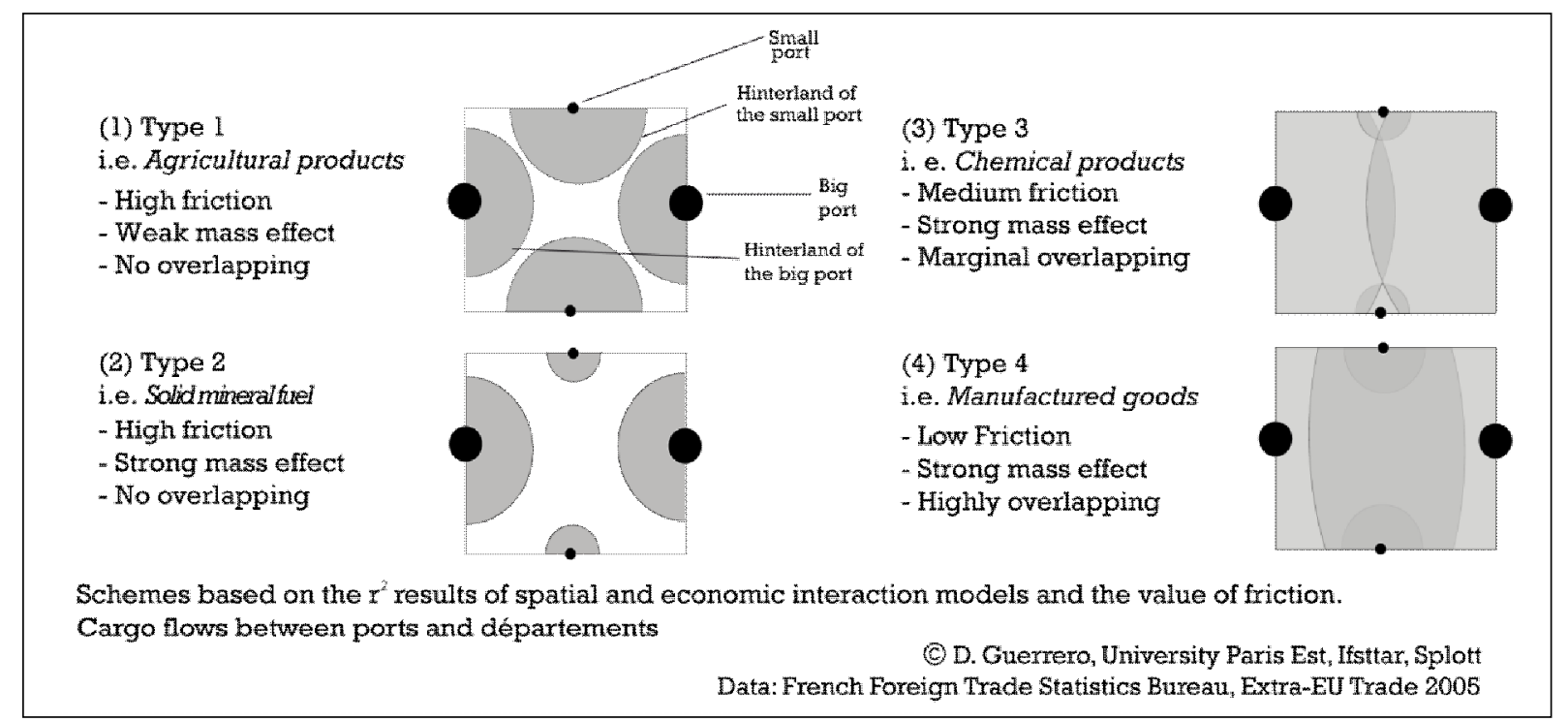

Figure 5. Typology of hinterlands based on the results of geographic and economic model

The high values of $\mathrm{r}^{\mathrm{Q}}$ could be associated with captive hinterlands, because most of the variance is explained by distance, that is, flows are handled by the nearest port. On the contrary, low values of $\mathrm{r}^{\mathrm{Q}}$ indicate that distance explains only a small part of the spatial distribution of flows, indicating substantially overlapped hinterlands, where competition between ports could virtually take place. Using both values of friction (? ? and the part of variance specifically explained by distance $\left(\mathrm{r}^{[}\right)$for distinguishing and grouping types of cargo flows, one can generalize with respect to the size of ports and the extent and overlapping of hinterlands. Such generalization leads to a typology of hinterlands having four basic types (Figure 5):

- The first type of hinterlands are defined by a weak mass effect and a strong friction (for example, agricultural products). The size of the département is of no consequence, because the activities generating cargo flows do not need to be too close to markets or populations. On the contrary, it is in low densely populated départements that most of flows are generated. The size of ports has no effect. Either small (except the ports of Languedoc) or large ports (except Rouen) can handle this cargo, which mainly consists of dry bulks. Ships are tramping and convey full loads. Shippers search to minimize inland haulage, because this kind of cargo cannot absorb high inland transport costs.

The second type of hinterlands display a strong mass effect and high friction (for example, petroleum products). Short flows predominate in them, because of the high friction or cost of overcoming distance. This is particularly true at the level of port industrial zones where ports and goods are co-located. In the main port industrial zones of Marseilles-Fos, Le Havre, and Dunkirk, most of the traffic is conveyed across relative short distances. Therefore the high value of the distance decay function is 
strongly driven by intra-port flows, where industrial activities and ports are co-located. It should also be noted that port accessibility has a strong influence in the choice of location of these kind of facilities, such petrochemical plants. This preference for proximity gives competitive advantage to port regions in attracting manufacturing activities (Fujita and Mori, 1996, cited in Ducruet et al., 2009).

The third type of hinterland has strong mass effect and medium friction (for example, chemical products). In these locations, cargo is shipped over longer distances to the industries and to markets located in inland départements (for example, Lyon area) but there is little overlapping between hinterlands.

The fourth type of hinterlands has strong mass effect and weak friction. In these locations, manufactured cargo flows, where economies of scale of container ports play an important role and cargo is relatively valued high. The setting of hinterland accessibility strategies such as rail shuttles (Van Klink and Van den Berg, 1997, Gouvernal and Daydou, 2005, Debrie and Gouvernal, 2006), barge services (Frémont and Franc, 2010, Franc and Van der Horst, 2010) and inland terminals (Notteboom and Rodrigue, 2005, Rodrigue et al., 2010) also contribute to the lower friction of distance of these flows, which are mostly containerized. This type of hinterland is strongly influenced by the relative location of the consumer population and national markets. The inland départements that generate the most important manufacturing flows are those of Paris and large cities (with a population in excess of 200,000), where wholesalers are overrepresented (Guerrero and Proulhac, 2014). Largest départements and global ports have the largest flow volume and also undertake some of the longest hauls.

The results provided by the spatial interaction model suggest several things. First, the size of ports and départements are primary variables in explaining the pattern of export flows through the ports in the model. Large ports tend to have the largest number of port calls, serve most destinations, and boast the best of hinterland connections. The trend toward load centering and hubbing by the shipping lines has helped to encourage this trend. Inland urban areas are also crucial, because they help generate increasing amounts of cargo, especially manufactured flows. For the purposes of our study, however, distance remains a strong factor in the flow of cargo via seaports. Most types of cargo experience strong levels of distance-decay for exports and imports. Manufactured goods, mostly containerized, remain distance-constrained, but to a lesser extent than the other types of cargo. This might indicate that distance is a factor to contend with for both containerized and non-containerized cargo, but the dominance of big ports in manufactured goods (that is, containerized) is much important than for the other types of cargo. This tempers the argument that inland distance no longer matters in the seaport used (Van Klink and Van den Berg, 1997).

The model as proposed does not explain a minor proportion of the variance in the dataset. There are probably some variables, other than volume and distance, which have some effect on spatial structure of flows between ports and départements. Factors such as further information on the maritime portion of the voyage, which are not included in the present dataset, might help increase the explanatory power of the model. Anyway, it remains a fact that there are distinct catchment areas for different overseas regions. This idea is supported by Robinson (1970) who drew different tributary areas to the port of Vancouver for trade with Japan and United Kingdom. He found, in the North American context, that hinterlands and forelands were strongly linked and should be analyzed simultaneously. 


\section{Containerization has strengthened the link between hinterlands and forelands}

To test Robinson $\breve{s}$ hypothesis on the continuity between hinterland and foreland after containerization, a detailed study on the hinterlands of Le Havre and Marseilles was undertaken. It narrows focus on a longitudinal transect that follows the inland highway between both the ports (figure 6). The graph represents the local share of each port in the total maritime trade of the département.

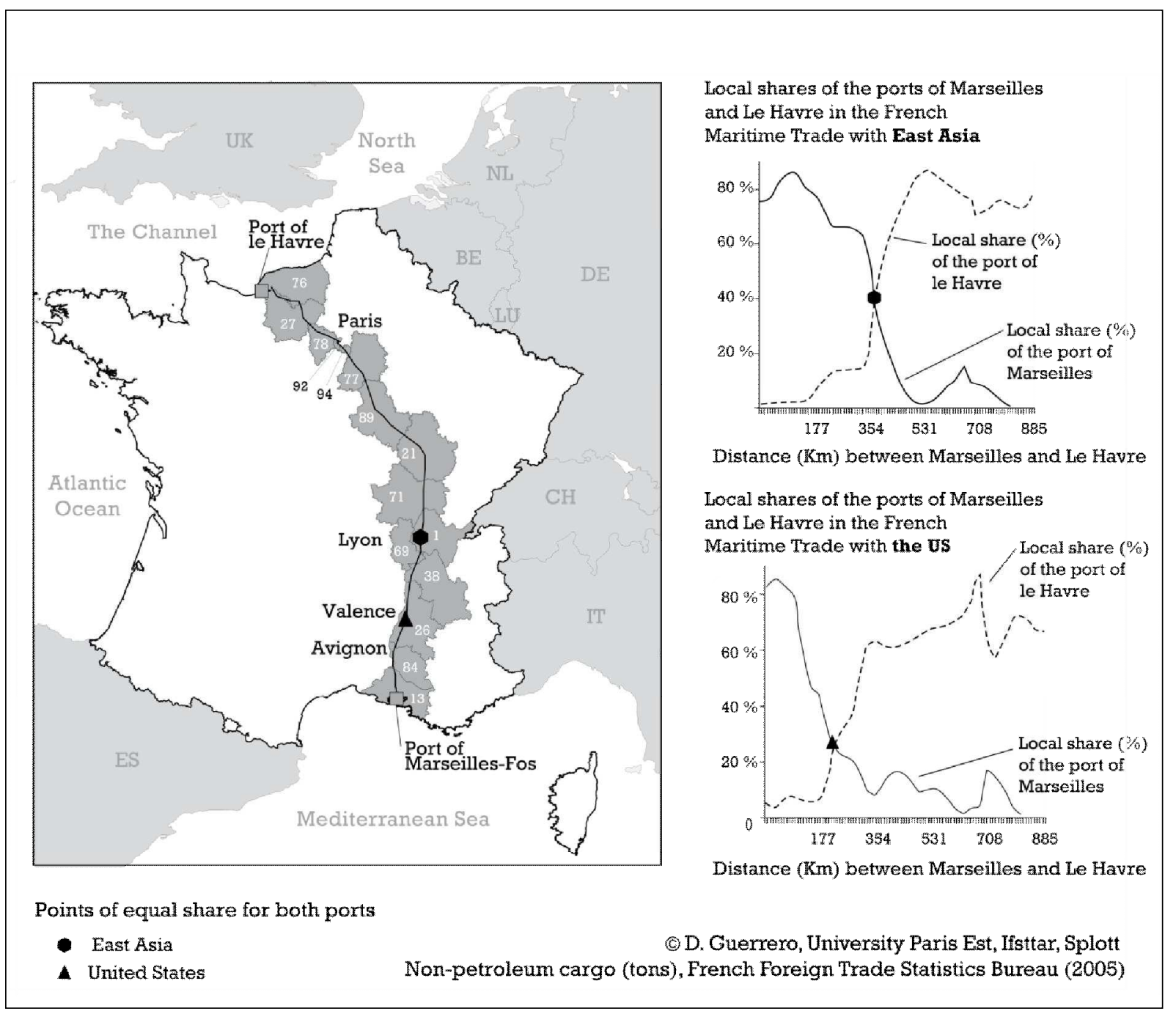

Figure 6. Hinterlands of Le Havre and Marseilles. Trade with East Asia and US

For trade with East Asia, the shares of both ports are very high on their primary hinterlands. Marseilles largely dominates the first $300 \mathrm{~km}$, then it decreases dramatically from Lyon, and increases slightly in the Paris region. In the case of Le Havre, the domination over other ports is less clear in the primary hinterland, where it shares the territory with the port of Rouen. Its share increases between 300 and $500 \mathrm{~km}$, in the region of Paris and beyond. Near Lyon, the hexagon-shaped symbol indicates that the shares of both ports are equal.

For trade with the United States, the lengths of the hinterlands of the two ports are very unequal. Marseilles only dominates the first few kilometres, and shows a dramatic decrease from Avignon. Le Havre keeps a high share of the U.S. maritime trade of départements up to 
Lyon and beyond. Between Valence and Avignon, the triangle-shaped symbol indicates that the shares of both ports are equal.

This analysis validates the hypothesis that there exists a hinterland ${ }^{-}$foreland continuum for global ports in France. Marseille s peripheral location at the southern end of France railroad has meant, in effect, that the port s competitors, rather than being on the same coastline, are in fact at the northern end of the highway or at least in the industrial heartland and major Canadian markets. The southward extension of the hinterland of Le Havre for U.S. maritime trade can be easily explained by its very frequent maritime services (Frémont and Soppé, 2007). Moreover, Le Havre is the last port of call for most of services between northern Europe and North America. French shippers in the foreland often prefer Le Havre, even if it would mean a larger inland haulage compared to Marseilles.

The situation is slightly different for East Asian trade, although Le Havre has unquestionably more frequent maritime links. This advantage is partially compensated by shorter transit times from Marseilles. The inland distance appears to be the factor that tips the balance in favor of one port or another.

\section{Conclusion}

"What seems to have emerged from the empirical work of the past dozen years is a compromise vision. Distance matters a lot, though possibly less than it did before modern telecommunications. Borders also matter a lot, though possibly less than they did before free trade agreements. The spaceless, borderless world is still a Platonic ideal, a long way from coming into existence."

Krugman, 2004, p. 13

Our results show that ports are not isolated from their hinterlands, and the main cargo flows take place between ports and local regions. In our analysis, the combined effect of the size (volume of cargo generated by ports and départements) and distance accounts for at least $86 \%$ variation in total flows and $69 \%$ in manufactured flows. The rest is probably due to foreland differentiation discussed earlier, strategies of the transport operators and governments concerning the ports they manage and/or for which they authorize development, specific geographies of niche markets and hub strategies (including direct rail links), and other specificities that cannot be included in a global model. As it is, the importance of distance in explaining hinterlands indicates that current inland connections are stable and path dependent over the long term.

Our results are particularly interesting in the light of Charlier s (1981) finding that French hinterlands remain largely constrained by distance. In our study, whereas the share of the hinterlands between gateways and secondary ports remains unchanged for all types of cargo, only the first can attract manufactured cargo flows. These seemingly contradictory results are in fact consistent one with another. With regard to containerized cargo, a select group of advantaged ports has benefited because containerization at the expense of many other ports, both large and small. With respect to bulks and short sea shipping, equalization is observed provoked by the development of niche markets, mainly driven by agriculture, forage, and forestry products.

Our conclusions are valid only for France. More empirical research is necessary to make further generalization to other European countries. Studies on inland countries such as as 
Austria show that competition between ports seems to be much fiercer since no single port has a cost advantage over the other ports (De Langen, 2007). The same gap between inland (competitive) and coastal (less competitive) states has been observed in the United States (Pitts, 1994, Levine et al, 2009). In Eastern Asia, most of sea markets are located near-shore and therefore hinterlands tend to be concentrated in the regions of ports (Lee et al. 2008, Itoh, 2013). In the specific case of China, the industrial development of the West is seen to be contributing to the increase of inland haulage and may probably lead to an increase in competition between ports.

There are several implications of this conclusion. First, port authorities must make difficult choices when deciding how and where to concentrate marketing efforts. Sometimes, port authorities tend to focus on competition margins without caring enough about the immediate hinterland wrongly assumed to be captive. This analysis finds that immediate hinterlands are not so captive (cf. Le Havre) and so the demand of local shippers must be taken seriously.

Second, hinterlands go beyond national borders (cf. Belgian and Dutch ports in Northern France). As argued earlier by Baird (2004), partially common hinterlands for global ports suggest the need for a more cohesive European policy for these ports in particular.

Last but not least, the model has also quantified the values of friction for different types of cargo. This is an important finding of our study as it provides an empirical support for visualizing scenarios with regard to the impact of abandoning secondary ports for economic activities such animal feeding. The stronger influence of friction relative to other factors in these hinterlands provides an empirical justification for giving priority to secondary ports in public policies.

The year of observation in this paper is 2005. The global financial crisis of 2008 has considerably impacted European demand for imported goods, implying a decline in traffic. Container throughput figures of main container ports serving France in 2009 were $11 \%$ to $19 \%$ lower compared to 2008 . At the time of writing this paper, it was still too early to determine if the 2008 crisis has increased (or not) the gap between global and secondary ports. Notteboom (2010) points out two developments contributing to the enlargement of the hinterlands of global ports. On one hand, reconfigurations in liner services have resulted in cargo consolidation in larger ports, whereas on the other an increased geographical specialization of global ports is visible vis-à-vis specific overseas maritime regions. Following the examples of other countries (except Germany), France is expected to implement new rules to promote ecologically sustainable transport (except Ecotax) in the next few years. This will an impact on the price of road transport and will perhaps contribute to attracting containers to secondary ports. It is however not entirely clear at this point to what extent these trends will affect the hinterlands.

\section{Acknowledgements}

This research is part of my unpublished $\mathrm{PhD}$ Thesis at University Paris $7^{-}$Paris Diderot. Special thanks go, in particular, to my supervisors, Professors Jean Debrie (Univ. Paris 1) and Claude Grasland (Univ. Paris 7), for their helpful suggestions and discussions during the study. I wish to express my gratitude to IFSTTAR and AME-SPLOTT for offering financial assistance and first-class facilities during my study. I also thank the anonymous reviewers for their helpful and constructive comments that contributed to the improvement of the manuscript. 


\section{References}

Amphoux, M., 1950. Des horizons terrestres aux horizons maritimes de l冖activité portuaire. Revue de la Porte Océane, 6(57), 15-18.

Baird, A. J. 2004. Public goods and the public financing of major European seaports.

Maritime Policy \& Management, 31(4), 375-391.

Charlier, J. ,1981. Contribution méthodologique à l'étude des arrière-pays portuaires. Ph. D. Thesis, Université Catholique de Louvain.

Charlier, J.,1991. L'arrière-pays national du port du Havre : une approche macrogéographique. L'espace géographique, 20 (4), 325-334.

Charlier, J.,1996. The Benelux Seaport System, Tijdschrift voor economische en sociale geografie, 87 (4), 310³21.

Charlier, J., 2011. Hinterlands, port regionalisation and extended gateways: the case of Belgium and Northern France in: Hall P., McCalla R., Comtois C., Slack B., Integrating Seaports and Trade Corridors, Burlington-Farnham, Ashgate, p. 235-246

D'Aubigny, G., Calzada, C., Grasland, C., Robert, D.,2000. Approche poissonnienne des modèles d'interaction spatiale. Cybergéo, 126.

De Langen, P. W. (2007). Port competition and selection in contestable hinterlands; the case of Austria. European Journal of Transport and Infrastructure Research, 7(1), 1-14.

De Neufville, R., Tsunokawa, K., 1981, Productivity and Returns to scale of container ports, Maritime Policy and Management, 8(2), 121-129.

Debrie, J., Gouvernal, E. 2006. Intermodal rail in Western Europe: actors and services in a new regulatory environment. Growth and Change, 37(3), 444-459.

Debrie, J., Guerrero, D.,2008. (Re)spatialiser la question portuaire : pour une lecture géographique des arrière-pays européens, 37 (1), 45-56.

Demangeon, A., 1918. Anvers. Annales de géographie 148-149 (27), 307-339

Ducruet, C., Notteboom, T. E., \& De Langen, P. W. (2009). Revisiting inter-port relationships under the new economic geography research framework. Ports in Proximity: Competition and Coordination among Adjacent Seaports, 11-27.

Ducruet, C., Notteboom, T., 2010. The worldwide maritime network of container shipping: Spatial structure and regional dynamics, GaWC Research Bulletin, 364

Lee, S. W., Song, D. W., \& Ducruet, C. 2008. A tale of Asia s world ports: the spatial evolution in global hub port cities. Geoforum, 39(1), 372-385.

Frémont A., Soppé, M., 2007. Northern European range: shipping line concentration and port hierarchy, Proceedings of the International Workshop on Ports, Cities and Global Supply Chains (2005 : Hong Kong, China), 10-120. 
Frémont, A., Franc, P. 2010. Hinterland transportation in Europe: Combined transport versus road transport. Journal of Transport Geography, 18(4), 548-556.

Fotheringham, A. S., O'Kelly, M. E.,1989. Spatial Interaction Models : Formulations and Applications. Kluwer, Dordrecht and Boston.

Franc, P., \& Van der Horst, M. (2010). Understanding hinterland service integration by shipping lines and terminal operators: a theoretical and empirical analysis. Journal of Transport Geography, 18(4), 557-566.

Fujita, M., \& Mori, T. (1996). The role of ports in the making of major cities: selfagglomeration and hub-effect. Journal of Development Economics, 49(1), 93-120.

Gouvernal, E., Slack, B., Franc, P, 2010. Short sea and deep sea shipping markets in France, Journal of Transport Geography, 18(1), 97-103.

Gouvernal, E., Daydou, J. 2005. Container railfreight services in north-west Europe: diversity of organizational forms in a liberalizing environment. Transport Reviews, 25(5), 557-571.

Gouvernal, E., Debrie, J., \& Slack, B. 2005. Dynamics of change in the port system of the western Mediterranean. Maritime Policy \& Management, 32(2), 107-121.

Guerrero, D. 2010. Les aires d'influence des ports de la France: entre réseau et gravitation, PhD Thesis, Université Paris-Diderot-Paris 7, $310 \mathrm{p}$.

Guerrero, D., Proulhac, L. 2014 Freight flows and urban hierarchy. Research in Transportation Business \& Management, Article in Press.

Guerrero, D., Rodrigue, J. P. 2014. The waves of containerization: shifts in global maritime transportation. Journal of Transport Geography, 34, 151-164.

Hayuth, Y.,1981. Containerisation and the load center concept, Economic Geography, 57(2), 160-176.

Hoare,A.G.,1986. British ports and their export hinterlands: A rapidly changing geography. Geografiska Annaler. Series B, Human Geography, 68(1),29-40.

Itoh, H., 2013, Market Area Analysis of Ports in Japan: An Application of Fuzzy Clustering, presented at the 2013 international conference of the International Association of Maritime Economist (IAME), Marseille, France, July, 2013.

Krugman, P. 2004. The :new economic geography: Where are we? Unpublished manuscript. Department of Economics, Princeton University, 1-14.

Levine, B., Nozick, L., Jones, D.,2009. Estimating an origin-destination table for U.S. Imports of waterborne containerised freight. Transportation Research Part E, 45 (4), 611-626.

Marcadon, J.,1988. L'avant-pays des ports français : géopolitique des échanges maritimes entre la France et le monde. Masson, Paris.

Mayer, H.M.,1978. Current trends in Great Lakes shipping. GeoJournal, 11(2),7-22.

Morgan, F.W., 1948. The pre-war hinterlands of the German North Sea ports. Transactions and papers (Institute of British Geographers), 14(4), 45-55. 
$\mathrm{Ng}$, A., \& Yu, K. (2006). Assessing the attractiveness of ports in the North European container transhipment market: an agenda for future research in port competition. Maritime Economics \& Logistics, 8(3), 234-250.

Notteboom, T. E. 1997. Concentration and load centre development in the European container port system. Journal of transport geography, 5(2), 99-115.

Notteboom, T. 2005. The peripheral port challenge in container port systems. International maritime transport: perspectives, 173-188.

Notteboom, T. E., Rodrigue, J. P. 2005. Port regionalization: towards a new phase in port development. Maritime Policy \& Management, 32(3), 297-313.

Notteboom, T. E. 2010. Concentration and the formation of multi-port gateway regions in the European container port system: an update. Journal of Transport Geography, 18(4), 567-583.

Pitts, T.,1994. Interport competition and cargo tributary areas for international containerised exports from the United States. Ph. D. Thesis, State University of New York at Buffalo.

Rimmer P. J.,1967. The search of spatial regularities in the development of Australian seaports 1861-1961. Geografiska Annaler. Series B, Human Geography, 49 (1), 42-54.

Robinson, R.,1970. The hinterland-foreland continuum : Concept and methodology. The Professionnal Geographer, 22 (6), 307-310.

Rodrigue, J. P., Debrie, J., Fremont, A., \& Gouvernal, E. 2010. Functions and actors of inland ports: European and North American dynamics. Journal of Transport Geography, 18(4), 519529.

Sargent, A. J.,1938. Seaports and hinterlands, Adam and Charles Black, London.

Slack, B.,1990. Intermodal transportation in North America and the developmentof inland load centres. Professional Geographer 42(1), 72-83

Taaffe, E.J., R.L. Morrill, and P.R. Gould,1963. Transport expansion in underdeveloped countries: a comparative analysis, Geographical Review, 53, 503-529.

Van Klink, H.A., G.C. Van Den Berg, 1998. Gateways and intermodalism, Journal of Transport Geography, 6(1), 1-9.

Veldman, S. J., \& Bückmann, E. H. 2003. A model on container port competition: an application for the West European container hub-ports. Maritime Economics \& Logistics, $5(1), 3-22$.

Vigarié A.,1964. Les grands ports de commerce de la Seine au Rhin. Leur evolution devant 1 industrialisation des arrière-pays, Paris, Sabri.

Weigend, G.G.,1956. The problem of hinterland and foreland as illustrated by the port of Hamburg. Economic Geography, 32 (1), 1-16. 